\title{
Noncommunicable diseases and their common risk factors in Curitiba, Brazil: results of a cross-sectional, population-based study
}

\author{
Ana Maria Cavalcanti, ${ }^{1}$ Solena Ziemer Kusma, ${ }^{1}$ Eliane Regina da Veiga \\ Chomatas, ${ }^{2}$ Sérgio Aparecido Ignácio, ${ }^{3}$ Eugênio Vilaça Mendes, ${ }^{4}$ \\ Simone Tetu Moysés, ${ }^{3}$ and Roberto Pecoits-Filho ${ }^{1}$
}

Suggested citation

Cavalcanti AM, Kusma SZ, Chomatas E, Ignácio SA, Mendes EV, Moysés ST, et al. Noncommunicable diseases and their common risk factors in Curitiba, Brazil: results of a cross-sectional, population-based study. Rev Panam Salud Publica. 2018;42:e57. https://doi.org/10.26633/RPSP.2018.57

ABSTRACT Objective. To describe the estimated prevalence of noncommunicable diseases and their common risk factors among the adult population of Curitiba, Paraná, Brazil, based on results of the EPIdemiology of CURitiba: EvaluAtion of Noncommunicable diseases (EPICUREAN) study.

Methods. This was a cross-sectional, population-based survey of 1103 residents of Curitiba, grouped by age ( 18 - 39 years of age, $40-59$, and $\geq 60$ years), conducted in August 2013 August 2014. Household interviews, anthropometry, blood pressure measurements, and fasting capillary glycemia were performed during two visits to each participant. The analyses included frequency distribution and prevalence estimates of main outcomes. Prevalence estimates, weighted by age and sex, were presented as absolute numbers and percentages.

Results. Prevalence estimates for self-reported depression were $21.2 \%$; hypertension, $31.2 \%$; diabetes, 9.1\%; self-reported dyslipidemia, 21.7\%; obesity, 21.2\%; current smoking, $16.1 \%$; binge drinking, 23.4\%; and insufficient physical activity, 35.1\%. Prevalences of diabetes and hypertension were higher among individuals with less schooling and the elderly. Binge drinking and leisure-time physical activity were more prevalent in young adults. Men presented higher prevalences of overweight, current smoking, and harmful use of alcohol. Obesity and moderateto-severe risk of depression were more frequent among women and those with lower income.

Conclusions. The prevalence of NCDs and common risk factors among the adult population of Curitiba are high and reveal a gradient of vulnerabilities by age, sex, education level, and income. To address health inequities and meet the needs of different population groups, the health system should monitor NCDs and risk factors and implement equitable public health policies.

Keywords Chronic disease, epidemiology; depression; diabetes mellitus; hypertension; risk factors; Brazil.

School of Medicine, Pontifícia Universidade Católica do Paraná (PUCPR), Curitiba, Paraná, Brazil. Send correspondence to Ana Maria Cavalcanti,dra.anacavalcanti@gmail.com Program in Health Sciences, Epidemiol-
ogy, Universidade Federal do Rio Grande
do Sul, Porto Alegre, Rio Grande do Sul, Brazil.
School of Life Sciences, PUCPR, Curitiba, Paraná, Brazil.

Consultant to National Health Secretariat Council, Brasília, Brazil. 
In 2009, the Pan American Health Organization (PAHO) / World Health Organization (WHO) Country Office in Brazil launched the Laboratório de Inovações em Atenção às Condições Crônicas (Laboratory for Innovative Care for Chronic Conditions; LIACC), an initiative to generate evidence for good health care management within the Sistema Único de Saúde (Unified Health System; SUS) and to positively impact the management of noncommunicable diseases (NCDs) in Brazil. The LIACC was based on technical cooperation with the Ministry of Health $(\mathrm{MoH})$ of Brazil, as well as other local, public institutions (1).

This initiative was clearly linked with the country's "Strategic Plan of Action for Controlling Noncommunicable Diseases in 2011 - 2022" (2). This plan, instituted by the $\mathrm{MoH}$, aims to deter the advancement of the four principle NCDs (cancers, cardiovascular diseases, chronic respiratory disease, and diabetes) and to reduce their shared modifiable risk factors (tobacco use, harmful use of alcohol, physical inactivity, and unhealthy diet). In keeping with the PAHO "Regional Strategy and Plan of Action on an Integrated Approach to the Prevention and Control of Chronic Diseases" (3) and the WHO "Global Action Plan for the Prevention and Control of NCDs 2013 $2020^{\prime \prime}$ (4), the Brazilian plan addresses strategies for surveillance, monitoring, evaluation, prevention, and health promotion, as well as management proposals for comprehensive health care (2).

Inequalities in NCDs and their common risk factors are well established and extensively connected with social inequalities (5-6). Identifying vulnerabilities and striving for health equity in all policies are core principles of the Commission on the Social Determinants of Health (7), placing inequality squarely on the political agendas of governments. In Curitiba, as in other large, Latin American cities, intra-urban social and health inequalities represent a challenge for public health managers.

Curitiba is the capital of the Paraná, a state in the southern part of Brazil. It has approximately 1.9 million inhabitants (8). Since 1999, the Municipal Secretariat of Health has organized Health Care Networks and has adopted chronic disease management programs in Curitiba. Based on the Chronic Conditions Care Model (CCCM), introduced by Mendes (9), the LIACC-Curitiba redesigned the health care approach according to the prevalence and risk stratification of depression, diabetes, and hypertension. Interventions addressing each CCCM level took into account the social determinants of health and the presence of risk factors and chronic conditions. In addition, self-management support and group visits were launched (9). However, local, population-based, epidemiological studies to back these actions were lacking.

To generate data on NCD prevalence and risk factors among the adult population of Curitiba, the "EPIdemiology of CURitiba: EvaluAtion of Noncommunicable diseases" (EPICUREAN) study was designed. Its aim was to collect epidemiological information that would guide public health policies and help monitor and provide qualified care for adults, taking into account the specific vulnerabilities of various age groups $(2-4)$. With this in mind, the objective of this study was to describe the EPICUREAN baseline results for estimated NCD prevalence and common risk factors among the adult population of Curitiba.

\section{MATERIALS AND METHODS}

EPICUREAN was a cross-sectional, population-based study with a municipal scope, conducted from August 2013 - August 2014 in Curitiba, Paraná, Brazil.

\section{Study sample}

The study population was composed of residents from private households in Curitiba, 18 years of age and older, not pregnant, with autonomy to answer the questionnaire, and who agreed to participate by completing an informed consent form. The sample size was calculated using the estimated population of three age groups of interest: 18 - 39 years of age, $40-59$ years, and $\geq 60$ years (8); the estimated mean frequency of the most prevalent health condition-hypertension, $30 \%$ (10); an acceptable margin of error of $5 \%$; and a non-response rate of $20 \%$. It totaled 1161 participants (387 per age group).

The strategy used to access participants included the following. First, four of the nine health districts were selected to represent the city's diversity: geographic distribution (East, West, and South health macro-region), population profile (socioeconomic status, percentage of elderly, use of public and private health services), and the characteristics of health units (basic units and family health care units). Then, the total sample size was proportionally distributed in the health districts according to the size of the estimated population by age group, composing age-specific sample sizes. Then, 20 census tracts in each district were randomly selected from the Geographic Operating Base 2010 Demographic Census (8). From these tracts, blocks and the starting point of the block were randomly chosen. Field teams traveled these blocks in a clockwise direction to sequentially locate homes where a resident might be interviewed.

At eligible homes, the interviewer presented information on the research aims and identified all household adults. To avoid selection bias, only one consenting adult per household (within one of the three possible age groups) was selected to participate. The houses were visited in sequence until the required sample size for each age group was met. Interviews and physical exams were scheduled on days and times most convenient for the participants. Two visits per household were required.

\section{Study instrument and data collection}

The staff interviewers (medical graduates and graduate students in health sciences) were trained in a 40-hour workshop that addressed research objectives; random selection of the blocks from the census tracts, routes, location of households, and selection of participants; conducting interviews; calibration of physical exam; and recording and delivering data. Additional training materials were made available on paper and in electronic format. Research supervisors monitored the work done in the field.

A pilot study was performed in August 2013 on two census tracts. This experience made it possible to adjust all of the interview procedures and instrument, as well as to solidify plans for each visit. The first visit was allotted 60 minutes, and the second, 20 minutes.

Interviews and measurements were performed at the participants' homes from August 2013 - August 2014. Data was registered on electronic devices with study-specific software. 
Data collection followed the WHO STEPwise approach to noncommunicable disease risk factor surveillance (11), including Step 1 (questionnaire), Step 2 (physical measurements), and Step 3 (biochemical measurements), except for measurement of total cholesterol. Validated questionnaires $(11-13)$ included information on socioeconomic status (occupation, schooling, family income, marital status, and work), lifestyle, health status, follow-up and treatment of NCDs, and health services utilization.

Prevalence of chronic conditions. Self-reported morbidity was registered based on reporting of a doctor's diagnosis of depression, diabetes, dyslipidemia (high cholesterol and/or triglycerides), and/or hypertension. The assessment of risk/severity of chronic diseases included self-rated health, risk of depression, and type 2 diabetes. Depression was assessed by the Brazilian version of the Patient Health Questionnaire (PHQ-9) - the depression module of the Primary Care Evaluation of Mental Disorders (14). A total score $\geq 10$ on the PHQ-9 was considered a moderate-tosevere risk of depression (15).

Diabetes was assessed with the Finnish Diabetes Risk Score (FINDRISC; 16), the most commonly used scale for detecting undiagnosed diabetes. A total score of $\geq 15$ was considered a high 10 -year risk of developing diabetes. It included values for: age $(45-54$ years of age $=2 ; 55-64=3 ; \geq 65$ years of age $=4$ ); less than 4 hours/week of physical activity $=2$; daily consumption of fruits, berries, or vegetables $=1$; use of antihypertensive medication $=2$; family history of diabetes (first degree relative $=5$, second degree relative $=3$ ); measured body mass index (BMI; $25-29.9 \mathrm{~kg} / \mathrm{m}^{2}=1$ or $\geq 30 \mathrm{~kg} / \mathrm{m}^{2}=3$ ); waist circumference (WC; $80-88 \mathrm{~cm}$ for women or $94-$ $102 \mathrm{~cm}$ for men $=3, \geq 88 \mathrm{~cm}$ for women or $102 \mathrm{~cm}$ for men $=4$ ); and informed (history of) or measured, raised blood glucose $=5(16)$.

Behavioral risk and protective factors. The behavioral risk factors assessed were: current smoking; heavy drinking (weekly calculated drink consumption of $\geq 8$ for women or $\geq 15$ for men; 17 ); binge drinking (women $\geq 4$ or for men $\geq 5$ cans of beer, glasses of wine, or doses of cachaça, scotch, or distilled spirits on a single occasion in the past 30 days; 17); regular intake of sodas and artificial juices ( $\geq 5$ days/week); sausage and luncheon meat intake (> 1 day/week); high fat meat (meat with apparent fat and/or chicken with skin) intake (> 1 day/week); whole milk intake (> 1 day/week); insufficient physical activity ( $<150$ minutes of mild/moderate or 75 minutes of intensive physical activity per week including leisure time, occupation, and transportation). Protective factors comprised recommended fruit and vegetable intake ( $\geq 5$ days/week in 5 portions/day-minimum of 1 portion of fruit/juice and 2 portions of vegetables / berries) and leisure-time physical activity ( $\geq 150$ minutes of moderate or 75 minutes of vigorous physical activity per week; $11-13)$.

Physical exam. The measured diseases and conditions included: nutritional status (overweight: BMI $25-30 \mathrm{~kg} / \mathrm{m}^{2}$; obesity: $\left.\mathrm{BMI} \geq 30 \mathrm{~kg} / \mathrm{m}^{2}\right)$; central obesity (WC $\geq 102 \mathrm{~cm}$ in men and $\geq 88 \mathrm{~cm}$ in women); hypertension (mean systolic blood pressure $[\mathrm{BP}] \geq 140 \mathrm{mmHg}$ and/or diastolic $\mathrm{BP} \geq 90 \mathrm{mmHg}$ and/or currently taking prescribed antihypertensive medication); and diabetes (fasting capillary glycemia $\geq 126 \mathrm{mg} / \mathrm{dL}$ and/or prior diagnoses of diabetes).

The physical exam and capillary glycemia were performed at home according to standard technical recommendations. BMI was calculated by the ratio of weight in kilograms to height in meters squared $(11,18)$. Weight and height, and arm, neck, and waist circumference, were measured using a calibrated, portable, digital scale (Marte $^{\circledR}$ LC/200PS, Marte Científica Inc., São Paulo, Brazil), a portable stadiometer (Alturexata, ${ }^{\circledR}$ Alturexata Inc., Belo Horizonte, Minas Gerais, Brazil), and a non-stretch tape measure (18). BP was measured after 5 minutes of rest, with the participant in a seated position, using a validated oscillometric device $\left(\right.$ Omron $^{\circledR}$ HEM 7113, Omron Healthcare Inc., Kyoto, Japan) and appropriately sized arm cuff (Omron ${ }^{\circledR}$ adult small, medium, or large; Omron Healthcare Inc., Kyoto, Japan; 11). Three measurements were taken on the right arm after 2-minute intervals, and casual BP was calculated by the arithmetic mean of the last two results (19). A fasting capillary glycemia test $(20,21)$ was taken during the second visit, after an 8-hour fasting period, by photometry (Accu-chek $^{\circledR}$ Active meter and Accu-chek ${ }^{\circledR}$ test strips, Roche Diagnostics Inc., a F. Hoffmann La-Roche company, Mannheim, Germany), presenting a variation from $10 \mathrm{mg} / \mathrm{dL}-600 \mathrm{mg} / \mathrm{dL}$.

\section{Data analyses}

Data processing and statistical analyses were performed using IBM SPSS Statistics software, version 20 (SPSS Inc., an IBM company, Chicago, Illinois, United States). Analyses included frequency distribution and prevalence estimates of main outcomes by age groups. Chi-squared tests were used to analyze associations between variables. An alternative weight approach was used to allow generalization of the results for the city population. For this, weighted prevalence estimates by age and sex were obtained by the ratio of the estimated total size of the population of a specific age group by sex per the sample size of the same, and were described as absolute numbers and percentages.

\section{Ethics}

This study was approved by the Research Ethics Committee of the Pontifical Catholic University of Paraná (Curitiba, Paraná, Brazil; Protocol 362.266) and the Research Ethics Committee of the Municipal Secretariat of Health (Curitiba, Paraná, Brazil; Protocol 25/2013). Participants signed an informed consent, and to guarantee anonymity of the data, no identifiable individual data was published or shared.

\section{RESULTS}

Considering the previously-calculated, age-specific sample size per health district, the total response rate was $95 \%$. The final sample size analyzed was 1103 participants. Of the original 1161 participants, 58 did not complete the second visit (45 were not available, 12 refused to participate, and 1 died during the period between visits).

Participant characteristics are presented in Table 1 . The majority were white $(80.1 \%$; 95\% Confidence Interval $[95 \% \mathrm{CI}]=77.7-82.5)$, currently working $(51.3 \%$; $95 \% \mathrm{CI}=48.4-54.2)$, and had a college education or higher $(\geq 12$ years of study; $36.5 \%$; $95 \% \mathrm{CI}=33.7$ - 39.3).

Table 2 presents the crude prevalence of chronic conditions and risk and protective factors by age group. Except for 
TABLE 1. Sociodemographic characteristics, by sex, according to the Epidemiology of Curitiba: Evaluation of Noncommunicable Diseases (EPICUREAN) study, Curitiba, Paraná, Brazil, 2013 - 2014

\begin{tabular}{|c|c|c|c|c|c|c|c|}
\hline \multirow{2}{*}{ Characteristics } & \multicolumn{2}{|c|}{ Overall $(n=1103)$} & \multicolumn{2}{|c|}{ Women $(n=727)$} & \multicolumn{2}{|c|}{ Men $(n=376)$} & \multirow{2}{*}{$P$ value } \\
\hline & $\%$ & $95 \% \mathrm{Cl}^{\mathrm{a}}$ & $\%$ & $95 \% \mathrm{Cl}$ & $\%$ & $95 \% \mathrm{Cl}$ & \\
\hline Age groups & & & & & & & 0.45 \\
\hline $18-39$ years & 32.9 & $30.1-35.7$ & 31.6 & $28.3-35.0$ & 35.4 & $30.5-40.2$ & \\
\hline$\geq 60$ years & 33.0 & $30.2-35.8$ & 33.4 & $30.0-36.9$ & 32.2 & $27.5-36.9$ & \\
\hline Skin color (self-declared) & & & & & & & 0.51 \\
\hline Black & 3.5 & $2.4-4.6$ & 3.0 & $1.8-4.3$ & 4.5 & $2.4-6.6$ & \\
\hline Yellow & 1.2 & $0.6-1.8$ & 1.1 & $0.3-1.9$ & 1.3 & $0.2-2.5$ & \\
\hline Native Indian & 0.1 & $0.0-0.3$ & 0.0 & $0.0-0.0$ & 0.3 & $0.0-0.8$ & \\
\hline Education level & & & & & & & $<0.001$ \\
\hline Elementary or less & 34.5 & $31.7-37.3$ & 36.7 & $33.2-40.2$ & 30.3 & $25.7-35.0$ & \\
\hline Secondary & 28.9 & $26.2-31.6$ & 30.8 & $27.5-34.2$ & 25.3 & $20.9-29.7$ & \\
\hline Never worked & 9.0 & $7.3-10.7$ & 11.8 & $9.5-14.2$ & 3.5 & $1.6-5.3$ & \\
\hline Currently working & 51.3 & $48.4-54.2$ & 44.8 & $41.2-48.5$ & 63.8 & $59.0-68.7$ & \\
\hline Not currently working & 17.9 & $15.6-20.2$ & 23.5 & $20.4-26.6$ & 6.9 & $4.4-9.5$ & \\
\hline Retired/on leave & 21.8 & $19.4-24.2$ & 19.8 & $16.9-22.7$ & 25.8 & $21.4-30.2$ & \\
\hline Household monthly per capita income MW' & & & & & & & $<0.001$ \\
\hline 1st quintile & 20.8 & $18.4-23.2$ & 24.2 & $21.0-27.4$ & 14.1 & $10.5-17.7$ & \\
\hline 2nd quintile & 23.9 & $21.3-26.5$ & 23.5 & $20.4-26.6$ & 24.6 & $20.2-29.0$ & \\
\hline 3rd quintile & 16.7 & $14.5-18.9$ & 17.4 & $14.6-20.2$ & 15.2 & $11.5-18.9$ & \\
\hline 4th quintile & 19.3 & $16.9-21.7$ & 18.8 & $15.9-21.7$ & 20.2 & $16.1-24.3$ & \\
\hline 5th quintile & 19.5 & $17.1-21.9$ & 16.1 & $13.4-18.8$ & 26.0 & $21.5-30.5$ & \\
\hline
\end{tabular}

${ }^{a}$ Confidence Interval.

${ }^{\mathrm{b}}$ Chi-squared test.

${ }^{c}$ Minimum Wage: total gross household monthly income divided by the total number of family members. Brazilian MW in January 2014 was R\$724.00 (US\$ 300.17 ).

Source: Prepared by the authors based on the EPICUREAN study results.

depression, the prevalence of chronic conditions was higher among the elderly, as was the 10-year high-risk of developing diabetes (FINDRISC $\geq 15$ ) and central obesity. More than one-half (56.3\%; $95 \% \mathrm{CI}=51.2-61.4)$ of these participants were not achieving sufficient weekly physical activity. Despite this, harmful alcohol consumption and poor diet (fatty meat, sausage/luncheon meat, and sweet beverages) were less prevalent in this group when compared to young adults (18- 39 years of age).

Weighted prevalence estimates by sex and age group are shown in Table 3. Men reported lower recommended weekly intake of fruits and vegetables $(28.8 \%$; $95 \% \mathrm{CI}=24.9-32.7$ vs. $37.2 \% ; 95 \% \mathrm{CI}=$ 33.3 - 41.1) and higher consumption of fatty meat $(40.1 \% ; 95 \% \mathrm{CI}=35.9-44.3$ vs. $24.7 \%$; $95 \% \mathrm{CI}=21.2-28.2)$ and sausage and luncheon meat $(66.1 \% ; 95 \% \mathrm{CI}=$ 62.0 - 70.2 vs. $46.9 \%$; $95 \% \mathrm{CI}=42.9-50.9)$.
In addition, binge drinking (37.4\%; $95 \% \mathrm{CI}=33.2-41.6 \%$ vs. $11.1 \% ; 95 \% \mathrm{CI}=$ 8.6 - 13.6) and current smoking (19.6\%; $95 \% \mathrm{CI}=16.2-23.0$ vs. $12.9 \%$; $95 \% \mathrm{CI}=$ 10.2 - 15.6) were more frequent among men. Women, however, presented lower prevalence of sufficient leisure-time physical activity $(25.6 \%$; 95\%CI = $22.1-29.1$ vs. $40.2 \%$; $95 \% \mathrm{CI}=36.0-44.5)$.

Overall, the prevalences of diabetes and hypertension were $9.1 \%(95 \% \mathrm{CI}=7.4-$ $10.8)$ and $31.2 \%(95 \% \mathrm{CI}=28.5-33.9)$, respectively. Prior diagnosis of dyslipidemia was reported by $21.7 \%$ of the participants $(95 \% \mathrm{CI}=19.3-24.1)$. More than one-fifth of the adults were considered obese $(21.2 \%$; $95 \% \mathrm{CI}=18.8-23.6)$, with higher prevalence among women $(24.6 \%$; $95 \% \mathrm{CI}=21.1$ - 28.1).

Compared to men, women reported a higher frequency of previously diagnosed depression $(28.8 \%$; $95 \% \mathrm{CI}=25.1$ 32.5 vs. $12.5 \% ; 95 \% \mathrm{CI}=9.6-15.4)$, as well as moderate-to- severe risk of depression according to their PHQ-9 scores $(12.8 \%$; $95 \% \mathrm{CI}=10.1-15.5$ vs. $6.5 \%$; $95 \% \mathrm{CI}=4.4-8.6)$.

Figure 1 shows the prevalence of selected chronic conditions and risk and protective factors according to education level and monthly per capita household income. Current smoking, diabetes, hypertension, and obesity were more frequent among individuals with only an elementary education ( $\leq 5^{\text {th }}$ grade). Obesity and moderate-to-severe risk of depression were more prevalent among participants in the lowest household income quintile than among those in the highest.

\section{DISCUSSION}

EPICUREAN is the first population-based study of a representative sample for NCDs in Curitiba. Not only 
TABLE 2. Prevalence of chronic conditions and risk and protective factors, by age group, according to the Epidemiology of Curitiba: Evaluation of Noncommunicable Diseases (EPICUREAN) study, Curitiba, Paraná, Brazil, 2013 - 2014

\begin{tabular}{|c|c|c|c|c|c|c|c|}
\hline \multirow[t]{2}{*}{ Variable } & \multicolumn{2}{|c|}{$\begin{array}{c}18-39 \text { years of age } \\
(n=363)\end{array}$} & \multicolumn{2}{|c|}{$\begin{array}{c}40-59 \text { years of age } \\
(n=376)\end{array}$} & \multicolumn{2}{|c|}{$\begin{array}{c}\geq 60 \text { years of age } \\
(n=364)\end{array}$} & \multirow[t]{2}{*}{$P$ value $^{\mathrm{b}}$} \\
\hline & $\%$ & $95 \% \mathrm{Cl}^{\mathrm{a}}$ & $\%$ & $95 \% \mathrm{Cl}$ & $\%$ & $95 \% \mathrm{Cl}$ & \\
\hline Recommended fruit and vegetable intake & 28.4 & $23.8-33.0$ & 38.3 & $33.4-43.2$ & 44.5 & $39.4-49.6$ & $<0.001$ \\
\hline Regular intake of soda and artificial juices & 39.7 & $34.7-44.7$ & 30.3 & $25.7-34.9$ & 18.4 & $14.4-22.4$ & $<0.001$ \\
\hline Whole milk intake & 56.5 & $51.4-61.6$ & 58.8 & $53.8-63.8$ & 53.0 & $47.9-58.1$ & 0.284 \\
\hline High fat meat intake & 31.7 & $26.9-36.5$ & 31.1 & $26.4-35.8$ & 22.3 & $18.0-26.6$ & 0.007 \\
\hline Sausage and luncheon meat intake & 62.0 & $57.0-67.0$ & 47.9 & $42.9-52.9$ & 38.5 & $33.5-43.5$ & $<0.001$ \\
\hline Binge drinking & 27.5 & $22.9-32.1$ & 14.6 & $11.0-18.2$ & 8.0 & $5.2-10.8$ & $<0.001$ \\
\hline Heavy drinking & 12.4 & $9.0-15.8$ & 5.1 & $2.9-7.3$ & 3.3 & $1.5-5.1$ & $<0.001$ \\
\hline Current smoking & 15.2 & $11.5-18.9$ & 17.3 & $13.5-21.1$ & 11.0 & $7.8-14.2$ & 0.047 \\
\hline Sufficient leisure-time physical activity & 36.9 & $31.9-41.9$ & 25.0 & $20.6-29.4$ & 22.3 & $18.0-26.6$ & $<0.001$ \\
\hline Insufficient physical activity & 29.8 & $25.1-34.5$ & 38.3 & $33.4-43.2$ & 56.3 & $51.2-61.4$ & $<0.001$ \\
\hline Poor self-rated health & 6.9 & $4.3-9.5$ & 9.6 & $6.6-12.6$ & 8.5 & $5.6-11.4$ & 0.413 \\
\hline High risk of diabetes (FINDRISC ${ }^{c} \geq 15$ ) & 7.6 & $4.8-10.4$ & 27.1 & $22.3-31.6$ & 47.7 & $41.7-53.7$ & $<0.001$ \\
\hline Moderate to severe risk of depression (PHQ-9d score $\geq 10)$ & 11.0 & $7.8-14.2$ & 11.7 & $8.5-14.9$ & 6.9 & $4.3-9.5$ & 0.060 \\
\hline Overweight & 29.2 & $24.5-33.9$ & 38.0 & $33.1-42.9$ & 44.8 & $39.7-49.9$ & $<0.001$ \\
\hline Obesity & 16.3 & $12.5-20.1$ & 28.0 & $23.5-32.5$ & 28.0 & $23.4-32.6$ & $<0.001$ \\
\hline Central obesity & 35.3 & $30.4-40.2$ & 54.4 & $49.1-59.4$ & 69.0 & $64.2-73.8$ & $<0.001$ \\
\hline Dyslipidemia (self-reported) & 11.3 & $8.0-14.6$ & 30.9 & $26.2-35.6$ & 37.6 & $32.6-42.6$ & $<0.001$ \\
\hline Depression (self-reported) & 21.2 & $17.0-25.4$ & 26.3 & $21.8-30.8$ & 22.3 & $18.0-26.6$ & 0.482 \\
\hline Hypertension & 9.7 & $6.6-12.8$ & 40.6 & $35.6-45.6$ & 75.5 & $71.1-79.9$ & $<0.001$ \\
\hline Diabetes & 2.8 & $1.1-4.5$ & 10.7 & $7.6-13.8$ & 28.1 & $23.5-32.7$ & $<0.001$ \\
\hline
\end{tabular}

a Confidence Interval.

${ }^{\mathrm{b}}$ Chi-squared test.

c Finnish Diabetes Risk Score, only for non-diabetic individuals.

d Patient Health Questionnaire-9.

Source: Prepared by the authors based on the EPICUREAN study results.

does it estimate prevalence of chronic conditions, such as hypertension, diabetes, and depression, it also portrays the status of risk and protective factors among the adult population. Global, regional, and national recommendations point to the need for developing NCD action plans that are based on local data, ones that make evaluation and monitoring possible through indicators and targets $(2-4)$.

The Brazilian NCD plan (2), concomitantly with PAHO (3) and WHO action plans (4), puts into place a set of targets to be reached by 2022. One of the targets is to reduce obesity among adults (2). This seems improbable for Brazil and Curitiba, since according to Vigitel (12)a national telephone interview system that investigates NCDs and risk factors among adults living in Brazil's state capitals-obesity prevalence increased respectively from $11.8 \%$ (Brazil) and $12.6 \%$ (Curitiba) in 2006 to $18.9 \%$ (for both) in 2016. The findings of the present study showed overall obesity prevalence $(21.2 \%)$ to be similar to the Vigitel data, with higher frequency among women and those with less schooling and income. Although national targets regarding protective factors (2), such as leisure-time physical activity $(22.0 \%)$ and consumption of fruits and vegetables $(24.3 \%)$, were surpassed by the city, lower prevalence was seen among those with less schooling, revealing disparities in either risk or protective factors.

Concerning smoking prevalence, Vigitel 2016 documented an annual average decline of 0.62 percentage points in 10 years $(15.7 \%-10.2 \%)$, resulting from strong tobacco control in Brazil (12). However, the high frequency of current smokers (16.1\%) found by EPICUREAN was similar to the National Health Survey (NHS; 13) estimates for Paraná $(18.1 \% ; 95 \% \mathrm{CI}=15.6-20.8)$, leaving both the city and the state far from the Brazilian plan's target of 9.1\% (2). Economic and cultural factors may play a role in Curitiba's high smoking prevalence: tobacco production and processing are important economic activities in Paraná, and Curitiba is mostly inhabited by descendants of Europe where smoking prevalence is known to be high $(13,22)$.

The inverse relationship between smoking prevalence and lower income in Latin America and the Caribbean was evidenced by a recent review (23). Although our results did not confirm this fact, EPICUREAN did concur with the NHS (13) on the highest frequencies of smoking being among the younger agegroups and those with a lower level of education $(12,13,22)$.

Binge drinking is another municipal challenge. In EPICUREAN, its occurrence $(23.4 \%)$ was higher in relation to NHS $(13.7 \%$; $95 \% C I=13.1-14.2)$ and Vigitel $(19.1 \%$; $95 \% \mathrm{CI}=18.3-19.8)$ and far from the national target of $12 \%$ as well $(2,13,14)$. The higher prevalences found among men, young adults (18 - 39 years of age), and individuals with a higher education were consistent with national patterns $(12,13,24)$. In 2016, Brazil was ranked 6th in the Region of the Americas for estimated alcohol consumption per capita (25). Free market prices and social acceptance may be facilitating access to 
TABLE 3. Weighted prevalence by sex and age group of chronic conditions and risk and protective factors in population $\geq 18$ years age of according to the Epidemiology of Curitiba: Evaluation of Noncommunicable Diseases (EPICUREAN) study, Curitiba, Paraná, Brazil, 2013 - 2014

\begin{tabular}{|c|c|c|c|c|c|c|c|}
\hline \multirow[t]{2}{*}{ Variable } & \multicolumn{2}{|c|}{$\begin{array}{c}\text { Overall } \\
(n=1103)\end{array}$} & \multicolumn{2}{|c|}{$\begin{array}{c}\text { Women } \\
(n=588)\end{array}$} & \multicolumn{2}{|c|}{$\begin{array}{c}\text { Men } \\
(n=515)\end{array}$} & \multirow[t]{2}{*}{$P$ value $^{\mathrm{b}}$} \\
\hline & $\%$ & $95 \% \mathrm{Cl}^{\mathrm{a}}$ & $\%$ & $95 \% \mathrm{Cl}$ & $\%$ & $95 \% \mathrm{Cl}$ & \\
\hline Recommended fruit and vegetable intake & 33.3 & $30.5-36.1$ & 37.2 & $33.3-41.1$ & 28.8 & $24.9-32.7$ & 0.003 \\
\hline Whole milk intake & 57.3 & $54.4-60.2$ & 55.2 & $51.2-59.2$ & 59.6 & $55.4-63.8$ & 0.137 \\
\hline High fat meat intake & 31.9 & $29.1-34.7$ & 24.7 & $21.2-28.2$ & 40.1 & $35.9-44.3$ & $<0.001$ \\
\hline Sausage and luncheon meat intake & 55.8 & $52.9-58.7$ & 46.9 & $42.9-50.9$ & 66.1 & $62.0-70.2$ & $<0.001$ \\
\hline Heavy drinking & 9.3 & $7.6-11.0$ & 6.1 & $4.2-8.0$ & 13.0 & $10.1-15.9$ & $<0.001$ \\
\hline Current smoking & 16.1 & $13.9-18.3$ & 12.9 & $10.2-15.6$ & 19.6 & $16.2-23.0$ & 0.002 \\
\hline Sufficient leisure - time physical activity & 32.4 & $29.6-35.2$ & 25.6 & $22.1-29.1$ & 40.2 & $36.0-44.5$ & $<0.001$ \\
\hline Insufficient physical activity & 35.1 & $32.3-37.9$ & 41.2 & $37.2-45.2$ & 28.2 & $24.3-32.1$ & $<0.001$ \\
\hline Poor self - rated health & 8.0 & $6.4-9.6$ & 8.1 & $5.9-10.3$ & 7.8 & $5.5-10.1$ & 0.822 \\
\hline High risk of diabetes (FINDRISC $\geq 15)^{c}$ & 18.1 & $15.7-20.5$ & 21.9 & $18.4-25.4$ & 13.9 & $10.8-17.0$ & $<0.001$ \\
\hline Central obesity & 43.1 & $40.2-46.0$ & 58.2 & $54.2-62.2$ & 25.9 & $22.1-29.7$ & $<0.001$ \\
\hline Dyslipidemia (self-reported) & 21.7 & $19.3-24.1$ & 23.0 & $19.6-26.4$ & 20.2 & $16.7-23.7$ & 0.443 \\
\hline Depression (self-reported) & 21.2 & $18.8-23.6$ & 28.8 & $25.1-32.5$ & 12.5 & $9.6-15.4$ & $<0.001$ \\
\hline Hypertension & 31.2 & $28.5-33.9$ & 28.2 & $24.6-31.8$ & 34.6 & $30.5-38.7$ & 0.021 \\
\hline Diabetes & 9.1 & $7.4-10.8$ & 10.1 & $7.7-12.5$ & 8.0 & $5.7-10.3$ & 0.236 \\
\hline
\end{tabular}

alcohol beverages and encouraging consumption (24).

Halting the rise of diabetes in adults is a major challenge worldwide, especially in low- and middle-income countries where prevalence increased faster (26, 27). By 2014, approximately $15 \%$ of adults living with diabetes were in the Americas, 2.8\% in Brazil (26, 27). By 2016, diabetes had become the 3rd leading cause of Disability-Adjusted Life-Years (DALYs) in Latin America and the Caribbean (excluding high-income countries) and the 8th in Brazil (28). In 2006 - 2016, the frequency of self-reported diabetes increased about $62 \%$ in Brazil (from $5.5 \%$ to $8.9 \%$ ) and $96 \%$ in Curitiba (from $4.9 \%$ to $9.6 \%$ ), according to Vigitel (12). Our results showed a similar overall prevalence $(9.1 \%)$, with higher frequencies observed among the elderly and individuals with less schooling (12). Awareness of diabetes (78\%) was higher than in most countries of Latin America and the Caribbean (50\%), as was glycemic control (84.1\%) (29). About one-quarter
$(22.9 \%)$ of individuals presented a high 10-year risk of diabetes according to the FINDRISC.

In 2016, high blood pressure was one of the three leading risk factors in terms of attributable DALYs at the global level (30). While WHO targeted (4) a $25 \%$ reduction in its prevalence, the Government of Brazil (2) adopted population strategies and targets, such as reduction of dietary salt and sedentary lifestyle, as well as early detection and treatment of hypertension. Countries in Latin America and the Caribbean had the highest hypertension prevalence estimates $(39.1 \%)$ across low- and middle-income countries (32.3\%); (31). Our findings were consistent with these results and with estimates of high blood pressure, not considering current medication, in Brazil (22.4\% in EPICUREAN; $22.8 \%$ in NHS). Likewise, the prevalence was higher among men and the elderly, and was inversely proportional to educational level, resulting in a downward socioeconomic gradient $(31,32)$.
By 2016, Depressive Disorders were the 9th leading cause of DALYs worldwide (28). In the presence of comorbidities, such as diabetes, dyslipidemia, and hypertension, depression is associated with lower drug compliance and poorer prognoses (33). The frequency of diagnosis of depression at some point in life reported by our study $(21.2 \%$; $95 \% \mathrm{CI}=$ 18.8 - 23.6) is in line with those estimated by the World Health Survey (34) for Brazil (19.2\%). However, the NHS (13) showed a self-reported depression prevalence of $7.6 \%(95 \% \mathrm{CI}=7.2-8.1)$ for Brazil and $12.6 \%(95 \% \mathrm{CI}=11.2-13.9)$ in its South region. Nearly 1 in 10 individuals presented moderate-to-severe risk of depression by the PHQ-9 in EPICUREAN. High risk of depression was more frequent among women and among adults at the lowest levels of education and income.

The presence of risk factors and chronic conditions shown by EPICUREAN allow for the categorizing of the 5 CCCM levels in Curitiba (9). At Level 1, 
FIGURE 1. Weighted prevalence by sex and age group of selected chronic conditions and risk and protective factors, by education level and monthly household per-capita income, according to the Epidemiology of Curitiba: Evaluation of Noncommunicable Diseases (EPICUREAN) study, Curitiba, Paraná, Brazil, 2013 - 2014

Education level: $\square$ Elementary or less $\square$ Secondary $\square$ College or above
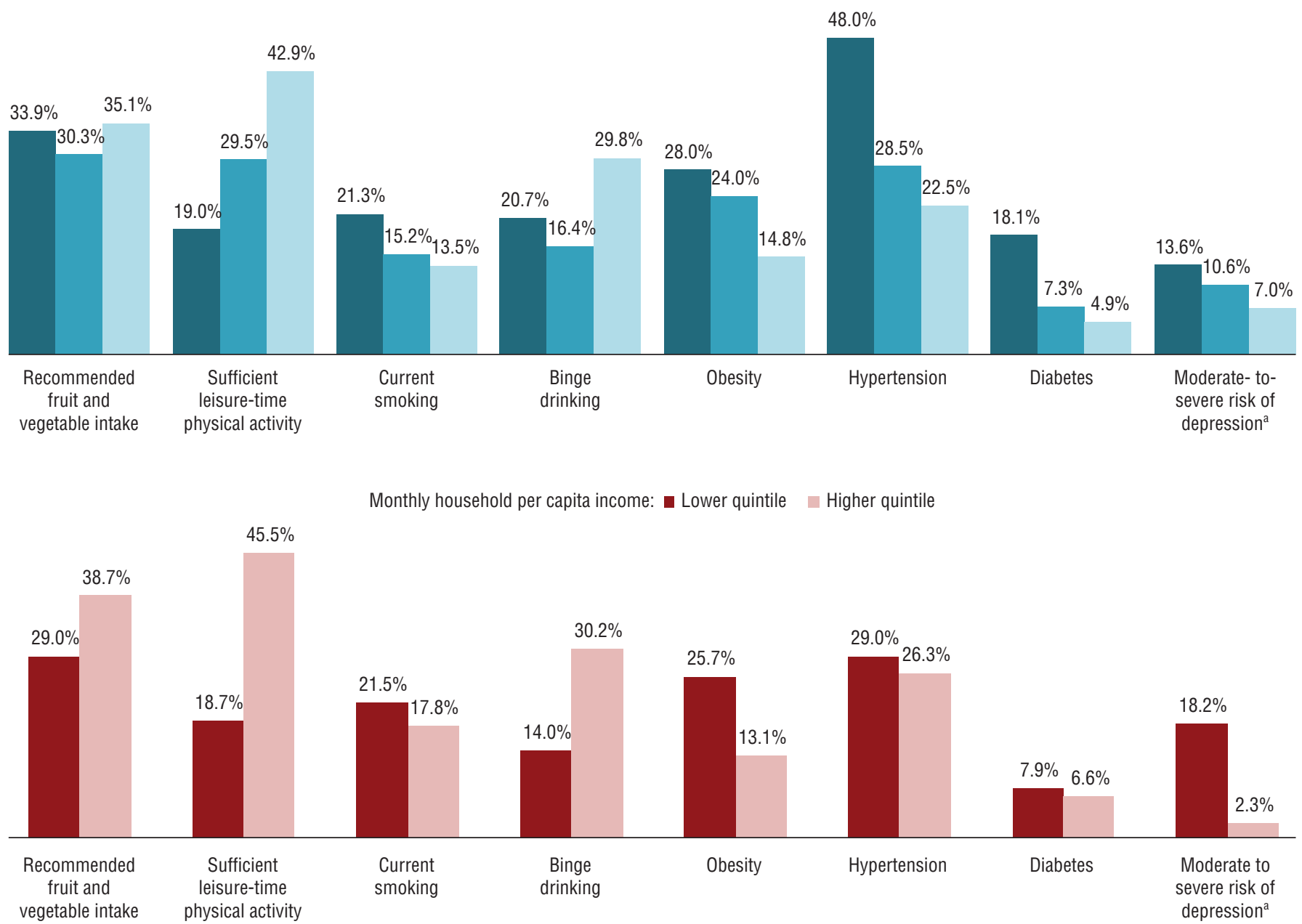

a Risk of depression based on a Patient Health Questionnaire- 9 score $\geq 10$

Source: Prepared by the authors based on the EPICUREAN study results.

interventions should focus on intermediate social determinants of health (living and working conditions) reaching the entire municipal population. At Level 2, interventions should be directed to proximal determinants (smoking, overweight, insufficient physical activity, unhealthy eating, and excessive alcohol use) and may occur in macro-, middle-, and/or micro-level environments. Disease management of established conditions (depression, diabetes, hypertension, and obesity) characterizes interventions for Level 3 - Level 5, based on risk stratification (presence of complications, comorbidity, and unfavorable socioeconomic condition). At Level 5, case management is usually required (9). At all levels, strategies that take into account vulnerable populations should be considered (7).

\section{Limitations}

EPICUREAN had some limitations. Selecting four of the nine geographic areas within Paraná limited the equal probability of participation by the adult population. Although the study included a higher percentage of women, this fact was minimized by weighting the results in the analysis. A comparative analysis of selected sociodemographic data (schooling, income, and race), weighted by sex and age groups, confirmed the representativeness and external validity of the sample in accordance with the Brazilian census (8). Fieldwork timing may also be considered a limitation since 12 months were required to complete data collection; but despite possible seasonal influences, results were consistent with other Brazilian surveys $(12,13)$. Moreover, it is well known that self-reporting is subject to bias, though widely used even in national health surveys $(12,13)$. Regarding diabetes diagnosis, although the gold standard method (plasma glycemia) was not used, the capillary glycemia method has produced similar results for prevalence at the population level (21). 


\section{Conclusions}

In conclusion, EPICUREAN baseline results indicate that the prevalence of NCDs and common risk factors is high among the adult population of Curitiba. The results also reveal a gradient of vulnerabilities by age, sex, education, and income. This population-based information and its representativeness for Curitiba should allow comparisons in health behaviors and morbidity for the three target age groups. This information can support policy and decisionmaking for NCD control at the municipal level. In order to address health inequalities and meet the needs of the various population groups, health systems at the local level should monitor NCDs and risk factors with sound epidemiological information and develop and implement equitable public health policies.

Acknowledgements. The authors wish to thank the PAHO/WHO Country Office (Brasilia, Brazil), Conselho Nacional dos Secretários de Saúde (Brasilia, Brazil), and the Municipal Secretariat of Health of Curitiba (Paraná, Brazil).

Funding. This study was carried out in conjunction with the Pontificia Universidade Católica do Paraná (Curitiba,
Paraná, Brazil) and was financed by an agreement (BR/LOA/1200096.001) between the Associação de Cultura (Curitiba, Paraná, Brazil) and PAHO/WHO (Washington, DC, United States). The funders had no role in study design, data collection and analysis, decision to publish, or preparation of the manuscript.

\section{Conflict of interests: None declared.}

Disclaimer. Authors hold sole responsibility for the views expressed in the manuscript, which may not necessarily reflect the opinion or policy of the RPSP/ PAJPH and/or PAHO.

\section{REFERENCES}

1. Moysés ST, Silveira-Filho AD, Moysés SJ. A implantação do Modelo de Atenção às Condições Crônicas em Curitiba: resultados do Laboratório de Inovações sobre Atenção às Condições Crônicas na Atenção Primária em Saúde. 1st ed. Brasília-DF: OPAS/CONASS; 2013. Available from: http: / / apsredes.org/pdf/ Modelo_Atencao_Curitiba.pdf Accessed 10 March 2017.

2. Malta DC, Silva Jr JB da. O plano de ações estratégicas para o enfrentamento das doenças crônicas não transmissíveis no Brasil e a definição das metas globais para o enfrentamento dessas doenças até 2025: uma revisão. Epidemiol Serviços Saúde. 2013;22(1):151-64.

3. Pan American Health Organization. Regional strategy and plan of action on an integrated approach to the prevention and control of chronic diseases. Washington, DC: PAHO; 2007. Available from: www1. paho.org/english/ad/dpc/nc/reg-stratcncds.pdf?ua=1 Accessed 18 March 2017

4. World Health Organization. Global action plan for the prevention and control of NCDs 2013 - 2020. Geneva: WHO; 2013. Available from: www.who.int/nmh/publications/ncd-action-plan/en/ Accessed 3 April 2017.

5. Sommer I, Griebler U, Mahlknecht P, Thaler K, Bouskill K, Gartlehner G, et al. Socioeconomic inequalities in non-communicable diseases and their risk factors: an overview of systematic reviews. BMC Public Health. 2015;15:914.

6. Allen L, Williams J, Townsend N, Mikkelsen B, Roberts N, Foster C, et al. Socioeconomic status and non-communicable disease behavioural risk factors in low-income and lower-middle-income countries: a systematic review. Lancet Glob Heal. 2017;5(3): e277-89.

7. Marmot SM. Closing the health gap in a generation: the work of the Commission on Social Determinants of Health and its recommendations. Glob Health Promot. 2009;16(suppl 1):23-7.

8. Instituto Brasileiro de Geografia e Estatística. Brasil em Síntese, Paraná,
Curitiba, Panorama, 2017. Available from: https: / / cidades.ibge.gov.br/brasil/pr/ curitiba/panorama Accessed 2 April 2017.

9. Mendes EV. O cuidado das condições crônicas na Atenção Primária à Saúde. 1st ed. Brasília: OPAS; 2012. Available from: http:/ /bvsms.saude.gov.br/bvs/publicacoes/cuidado_condicoes_atencao_primaria_saude.pdf Accessed 11 March 2017.

10. Picon R V, Fuchs FD, Riegel G, Fuchs SC. Trends in prevalence of hypertension in Brazil: a systematic review with meta-analysis. PLoS One. 2012;7(10):e48255.

11. World Health Organization. STEPwise approach to surveillance (STEPS). Available from: www.who.int/chp/ steps/en/ Accessed 10 June 2012.

12. Brasil, Ministério da Saúde, Secretaria de Vigilância em Saúde. Vigitel Brasil 2016: vigilância de fatores de risco e proteção para doenças crônicas por inquérito telefônico. Brasília: Ministério da Saúde; 2017.

13. Instituto Brasileiro de Geografia e Estatística. Pesquisa Nacional de Saúde 2013: percepção de estado de saúde, estilo de vida e doenças crônicas. Rio de Janeiro: Ministério da Saúde; 2014.

14. Spitzer RL, Kroenke K, Williams JBW. Patient Health Questionnaire Primary Care Study Group. Validation and utility of a self-report version of PRIME-MD: the PHQ Primary Care Study. JAMA. 1999; 282(18):1737-44.

15. Kroenke K, Spitzer RL, Williams JBW. The PHQ-9: validity of a brief depression severity measure. J Gen Intern Med. 2001; 16(9):606-13.

16. Lindström J, Tuomilehto J. The Diabetes Risk Score. Diabetes Care. 2003;26(3): 725-31.

17. United States Centers for Disease Control and Prevention. Fact sheets: Preventing excessive alcohol use. Available from: https: / / www.cdc.gov/alcohol / factsheets/prevention.htm Accessed 11 March 2017.

18. Brasil, Ministério da Saúde, Secretaria de Atenção à Saúde, Departamento de Atenção Básica. Orientações para a coleta e análise de dados antropométricos em serviços de saúde: Norma Técnica do Sistema de Vigilância Alimentar e Nutricional. Brasília DF: Ministério da Saúde; 2011.

19. Pan American Hypertension Initiative. Working meeting on blood pressure measurement: suggestions for measuring blood pressure to use in populations surveys. Rev Panam Salud Publica. 2003;14(5): 300-2.

20. American Diabetes Association. Standards of medical care in diabetes, 2017. Diabetes Care. 2017;40(suppl 1):S1-132.

21. Tirimacco R, Tideman PA, Dunbar J, Simpson PA, Philpot B, Laatikainen T, et al. Should capillary blood glucose measurements be used in population surveys? Int J Diabetes Mellit. 2010;2(1):24-7.

22. Malta DC, Vieira ML, Szwarcwald CL, Caixeta R, Brito SMF, Reis AAC dos, et al. Smoking Trends among Brazilian population - National Household Survey, 2008 and the National Health Survey, 2013. Rev Bras Epidemiol. 2015;18(suppl 2):45-56.

23. Bardach A, Andrés H, Perdomo G, Amanda R, Gándara R, Ciapponi A. Income levels and prevalence of smoking in Latin America: a systematic review and metaanalysis. Rev Panam Salud Publica. 2016; 40(4):263-71.

24. Garcia LP, Freitas LRS de. Heavy drinking in Brazil: results from the 2013 National Health Survey. Epidemiol e Serviços Saúde. 2015;24(2):227-37.

25. World Health Organization. World Health Statistics 2017: Monitoring health for the Sustainable Development Goals. Geneva: WHO; 2017. Available from: www.who.int/gho/publications/world health_statistics/2017/en/ Accessed $2 \overline{2}$ April 2017.

26. NCD Risk Factor Collaboration. Worldwide trends in diabetes since 1980: A pooled analysis of 751 population-based studies with 4.4 million participants. Lancet. 2016;387(10027):1513-30.

27. World Health Organization. Global Report on Diabetes. Geneva: WHO; 2016 Available from: http:/ / apps.who.int/iris/bitstream/ 
10665/204871/1/9789241565257_eng.pdf Accessed 23 May 2017.

28. GBD 2016 DALYs, HALE Collaborators. Global, regional, and national disability -adjusted life-years (DALYs) for 333 diseases and injuries and healthy life expectancy (HALE) for 195 countries and territories, 1990-2016: a systematic analysis for the Global Burden of Disease Study 2016. Lancet. 2017;390(10100):1260-344.

29. Arredondo A, Azar A, Recamán AL. Diabetes, a global public health challenge with a high epidemiological and economic burden on health systems in Latin America. Glob Public Health. 2017;27:1-8.

30. Forouzanfar MH, Liu P, Roth GA, Ng M, Biryukov S, Marczak L, et al. Global burden of hypertension and systolic blood pressure of at least 110 to $115 \mathrm{~mm} \mathrm{Hg}$, 1990-2015. JAMA. 2017;317(2):165.

31. Sarki AM, Nduka CU, Stranges S, Kandala N-B, Uthman OA. Prevalence of hypertension in low- and middle-income countries. Medicine (Baltimore). 2015;94(50):e1959.

32. Malta DC, Santos NB dos, Perillo RD, Szwarcwald CL, Malta DC, Santos NB dos, et al. Prevalence of high blood pressure measured in the Brazilian population, National Health Survey, 2013. Sao Paulo Med J. 2016;134(2):163-70.

33. Grenard JL, Munjas BA, Adams JL, Suttorp M, Maglione M, McGlynn EA, et al. Depression and medication adherence in the treatment of chronic diseases in the
United States: A meta-analysis. J Gen Intern Med. 2011;26(10):1175-82.

34. Theme-Filha MM, Szwarcwald CL, Souza-Júnior PR. Socio-demographic characteristics, treatment coverage, and self-rated health of individuals who reported six chronic diseases in Brazil, 2003. Cad Saude Publica. 2005;21(suppl): S43-53.

Manuscript received on 8 March 2017. Accepted for publication on 22 November 2017.

Objetivo. Describir la prevalencia estimada de las enfermedades no transmisibles (ENT) y sus factores de riesgo comunes en los habitantes adultos de Curitiba (Paraná, Brasil), con base en los resultados del estudio sobre las características epidemiológicas

Enfermedades no transmisibles y sus factores de riesgo comunes en Curitiba, Brasil: resultados de un estudio transversal basado en la población

Palabras clave de Curitiba en el que se evaluaron las ENT (conocido como EPICUREAN por su acrónimo en inglés).

Métodos. Encuesta transversal, basada en la población, de 1103 habitantes de Curitiba, agrupados por edades (de 18 a 39 años, de 40 a 59 años y de 60 años en adelante), efectuada entre agosto del 2013 y agosto del 2014. Se realizaron entrevistas domiciliarias, antropometría y mediciones de presión arterial y glucemia capilar en ayunas en dos visitas a cada participante. Los análisis incluyeron distribución de frecuencias y cálculos de prevalencia de los principales resultados. Los cálculos de prevalencia, ponderados por edad y sexo, se presentaron como números absolutos y porcentajes.

Resultados. Las cifras de prevalencia de la depresión autonotificada fueron de 21,2\%; hipertensión, 31,2\%; diabetes, 9,1\%; dislipidemia autonotificada, 21,7\%; obesidad, 21,2\%; consumo actual de tabaco, 16,1\%; consumo compulsivo de bebidas alcohólicas, 23,4\%; y actividad física insuficiente, 35,1\%. La prevalencia de la diabetes y la hipertensión fue mayor en las personas con menor escolaridad y las de edad avanzada. El consumo compulsivo de bebidas alcohólicas y la actividad física en el tiempo libre fueron más prevalentes en los adultos jóvenes. Los hombres presentaron prevalencias más altas de consumo de tabaco, sobrepeso y consumo nocivo de alcohol. La obesidad y el riesgo de moderado a grave de depresión fueron más frecuentes en las mujeres y las personas de menores ingresos.

Conclusiones. La prevalencia de las ENT y los factores de riesgo comunes entre los habitantes adultos de Curitiba es alta y muestra un gradiente de vulnerabilidad por edad, sexo, nivel educativo e ingresos. Para abordar las inequidades en materia de salud y satisfacer las necesidades de diferentes grupos de población, el sistema de salud debe vigilar las ENT y sus factores de riesgo, y ejecutar políticas de salud pública equitativas.

Enfermedad crónica, epidemiología; depresión; diabetes mellitus; hipertensión; factores de riesgo; Brasil. 
RESUMO

\section{Doenças não transmissíveis e principais fatores de risco associados em Curitiba, Brasil: resultados de estudo transversal de base populacional}

Palavras-chave
Objetivo. Descrever a prevalência estimada de doenças não transmissíveis e principais fatores de risco associados na população adulta da cidade de Curitiba (PR), Brasil, de acordo com os resultados do estudo EPIdemiology of CURitiba: EvaluAtion of Noncommunicable diseases (EPICUREAN).

Métodos. Foi realizado estudo transversal de base populacional com 1.103 residentes da cidade de Curitiba, por faixas etárias (18-39, 40-59 e $\geq 60$ anos), em agosto de 2013 a agosto 2014. Foram conduzidas entrevistas domiciliares com medidas antropométricas e de pressão arterial e teste da glicemia capilar de jejum em duas visitas a cada participante. Foi analisada a distribuição da frequência e estimada a prevalência dos principais desfechos. As estimativas de prevalência, ponderadas por idade e sexo, foram apresentadas como números absolutos e porcentagens.

Resultados. Foram obtidas as seguintes estimativas de prevalência: 21,2\% para depressão autorreferida, 31,2\% para hipertensão, 9,1\% para diabetes, $21,7 \%$ para dislipidemia autorreferida, 21,2\% para obesidade, $16,1 \%$ para tabagismo atual, 23,4\% para uso excessivo de álcool e 35,1\% para nível insuficiente de atividade física. A prevalência de diabetes e hipertensão foi maior nos indivíduos com menor escolaridade e idosos. O uso excessivo de álcool e atividade física no lazer foram mais prevalentes em jovens adultos. Os indivíduos do sexo masculino apresentaram prevalência mais elevada de sobrepeso, tabagismo atual e uso prejudicial de álcool. Obesidade e risco moderado a grave de depressão foram mais frequentes no sexo feminino e em indivíduos de baixa renda.

Conclusões. Existe alta prevalência de doenças não transmissíveis e dos principais fatores de risco na população adulta de Curitiba, demonstrando um gradiente de vulnerabilidade por idade, sexo, nível de escolaridade e renda. Para abordar as iniquidades em saúde e suprir as necessidades dos diferentes grupos populacionais, o sistema de saúde deve monitorar as doenças não transmissíveis e os fatores de risco e implementar políticas de saúde pública equitativas.

Doença crônica, epidemiologia; depressão; diabetes mellitus; hipertensão; fatores de risco; Brasil. 